\title{
Modeling the Relationship between Economic Activity and Bank Loans to Private Sector: A Case of Turkey
}

\author{
Şehnaz Bakır Yiğitbaş and Birgül Cambazoğlu
}

\begin{abstract}
The main aim of this study is to investigate the relationship between deposit banks' aggregate commercial loans to the private sector, economic activities and interest rates in Turkey over the period from 2003:1 to 2013:2 by utilizing Johansen cointegration and error correction models. The cointegration analysis results show that there is a long-run relationship between bank loans, real gross domestic product and interest rates. Moreover, the Error Correction Model shows the existence of the short-run negative relationship between bank loans and interest rates. In contrast to that the results of the study do not support the existence of the shortrun relationship between bank loans and real gross domestic product.
\end{abstract}

Index Terms-Loans, GDP, interbank rate, Johansen cointegration test, VECM.

\section{INTRODUCTION}

The banking system's fundamental role in the financial market is to collect short-run deposits and to turn them into either short-run or long-run commercial and consumer loans, thereby providing liquidity for economic development [1], [2]. The Central Bank affects the liquidity ratio in financial market by using the monetary policy instruments that lead to contraction and expansion in the volume of loans. Through applying monetary policy, the Central Bank tries to achieve targeted basic macroeconomic variables such as interest rate, price stability, etc. Bank loans are one of the most significant tools employed to manage the economic system in accordance with the purposes of the monetary policy. In other words, the developments in the volume of loans in an economy are very important in the sense that they contain useful information that may be used in both the analysis and the estimation of economic activities [3].

In the literature, the relationship between bank loans, economic growth and crises are addressed and searched intensively. For instance, Gattin-Turkalj et al. [4], Demirguc-Kunt and Detragiache [2], Kaminsky and Reinhart [5] advocate that there exists a link between intense growth of loans and banking crises. Furthermore, various studies mention that banking crises have a negative impact on economic growth [6]-[9].

Manuscript received May 18, 2014; revised July 19, 2014.

Şehnaz Bakır Yiğitbaş is with the Department of Banking and Insurance, Ayvacik Vocational School of Higher Education, Çanakkale Onsekiz Mart University, Canakkale, Turkey (e-mail: sehnazbakir@comu.edu.tr).

Birgül Cambazoğlu is with the Department of International Trade and Business, Faculty of Business, Adnan Menderes University, Söke-Aydın, Turkey(e-mail: cambirgul@yahoo.com).
This study searches the impact of economic activities on bank loans, rather than the vice versa. Since the private sector's demand for loans is affected by economic developments as well as the cost of financing. This study deals with the bank loans granted by deposit banks to the private sector as a function of economic activity and interest rates. The main reason for focusing on deposit banks is that they have been dominating the financial system at an average rate of approximately $90 \%$ (see [10]). Therefore, it is important to analyze the relationship between loans supplied by deposit banks and the basic macroeconomic variables. In other words, the issue whether the relationship between the volume of loans granted by deposit banks to the private sector and the basic macroeconomic variables changes or not is getting more important. Also, the short run relationship is compared with long run to decide policies on economic development. In this framework, the study examines both the short-run and long-run relationships between the volume of loans granted by deposit banks to the private sector, economic activity level and interest rates in Turkey for the period between 2003Q1 and 2013Q2. The second section of the study includes summary of some empirical studies in which the relationships between loans, interest rates and economic growth are dealt with. The third section addresses econometric model and variables. The conclusion section evaluates the findings.

\section{LITERATURE REVIEW}

In the literature regarding bank loans, there are numerous studies that investigate the relationships between bank loans, economic activity and interest rate. Firstly, while some of the studies focus on the effects of economic activity and interest rate on bank loans, some others give emphasis on the effects of bank loans on economic growth. Secondly, some of the studies examine the relationship between bank loans, economic activity and interest rate both in the shortrun and long-run. In this context, considering the general trend in the empirical literature, it is clear that there exists a unidirectional causal relationship from economic activity and interests rates to bank loans, because of the nature of such relationship, these relations may changein a short-run and long-run. Some of the empirical studies on this issue are explained below.

Calza et al. [3] studied the determinants of private sector loans in the Eurozone for the period from 1980Q1 to 1999Q2. Using the real loan, real GDP and real interest rate variables, they examined the short-run relationship between these variables. They investigated the short-run and long-run relationships, respectively, by error correction model and Johansen cointegration. The basic findings obtained from 
this research suggest that there exists a positive relationship between real loans and real GDP in the long-run. In addition to that there is negative relationship between real loans and interest rates both in the short-run and long-run, and also long-run interest rates have more effect on private sector loans.

Gattin-Turkalj et al. [4] searched the relationship between real GDP and real loans for the economy of Croatian by using the least squares method. According to the analysis results, the changes in real GDP and real interest rates affect the loan behaviors, and also GDP is one of the most significant variable that affect the loan behavior. They concluded that there exists a strong and statistically significant relationship between loans and GDP.

In his study, Adamopoulos [11] employed the vector error correction model and used the Johansen cointegration test to analyze the short-run and long-run relationships between the loan market and economic growth in Spain for the period from 1976 to 2007. The results of the study show that economic growth and investments had a positive effect on the development of the loan market, whereas inflation affects the loan market negatively.

Onuorahand Ozurumba [1] searched the relationship between bank loans and economic growth in Nigeria for the period between 1980 and 2011. They concluded that not only bank loans for production but also overall aggregate commercial bank loans had positive effects on ratio of the economic growth for Nigeria. Moreover, they argued that there exists a short-run relationship between bank loan variables and the GDP variable, which is commonly accepted as an indicator of economic growth.

If we focus on studies conducted for Turkey, it is seen that the relationship between bank loans and economic growth is inquired through various methods. Excluding the study of Tuna and Bektas [12], the studies of Vurur and Özen [13], Kaya et al. [14] and İscan [15] conclude that there exists a relationship between economic growth and bank loans.

In their study, Vurur and Özen [13] investigated the relationship between savings, bank loans and economic growth in Turkey for the period from 1998Q1 to 2012Q1. According to the results of their Granger causality tests, there exists unidirectional causal relationship from bank deposits to economic growth and bank loans and also, from economic growth to bank loans. Furthermore, they emphasized that during the economic expansion period there was an increase in the volume of loans. The reason of that both firms and households increase their demand for loan able funds to finance their investment and consumption expenditure, respectively.

Kaya et al. [14] inquired the relationship between development level of financial markets and economic growth in Turkey for the period from 1998Q1 to 2009Q4 by employing the Least Squares Method.According to results of the tests (Johansen cointegration, Juselius cointegration and Granger causality tests), they found that the domestic volume of private sector loans affected economic growth and the private sector positively and also, added that these variables had a long-run relationship.

Iscan [15] questioned the effects of economic recessionperiod on the volume of loans forthe economy of Turkey. In her study, she found that the volume of loans was an important variable for economic growth, and concluded that economic contraction led to considerable contraction in the volume of loans as well for the concerned period.

Tuna and Bektas [12] examined the relationship between the domestic volume of loans by deposit banks and GDP in Turkey for the period between 1998 and 2012 through employing Gregory-Hansen cointegration test and Granger causality test. They found that there is neither Granger causality relationship nor long-run relationship between the variables.

Unlike the above-mentioned studies conducted on Turkish economy which used economic activity and bank loans in empirical analysis, this study also includesinterest rate variable. Furthermore, in this study cointegration test is used to find out the long-runrelationship between variables, and the error correction model is used to reveal the short-run relationship between the variables.

\section{EMPIRICAL ANALYSIS}

\section{A. Selection of Variables}

This study analyses the relationships between aggregate business loans granted by banks to the private sector $(L O A N)$, economic activity $(G D P)$ and the interbank offered rate in the money market (INT) for the period from 2003Q1 to 2013Q2 for Turkish economy.All variables, which weretaken from the Central Bank of the Turkish Republic Electronic Data Distribution System, were transformed from their nominal values into real values by using the CPI $(2003=100)$. Owing to fact that GDP variable involved seasonality, this variable was seasonally adjusted by the Census X12 method.

\section{B. Johansen Cointegration Test}

The aim of this study investigates the relationships between real loans, real GDP and real interest rates by using Johansen cointegration test and error correction model. The variables should be stationary at the same level in cointegration analysis. So that, we utilized Augmented Dickey-Fuller (ADF, [16]), Dickey-Fuller Generalized Least Squares (DF-GLS, [17]) and Kwiatkowski-PhillipsSchmidt-Shin (KPSS, [18]) for investigating stationarity.

TABLE I: RESULTS OF THE UNIT ROOT TEST

\begin{tabular}{lllllll}
\hline Variables & ADF (Level) & ADF $\left(1^{\text {st Dif. })}\right.$ & DF-GLS (Level) & DF-GLS $\left(1^{\text {st Dif. })}\right.$ & KPSS (Level) & KPSS $\left(1^{\text {st }}\right.$ Dif. $)$ \\
\hline LOAN & $-1.52(2)$ & $-5.14(1)^{*}$ & $0.53(2)$ & $-1.75(0)^{* * *}$ & $0.79(5)$ & $0.31(3)^{*}$ \\
GDP & $-2.37(1)$ & $-4.01(0)^{*}$ & $-0.38(1)$ & $-3.38(1)^{*}$ & $0.72(5)$ & $0.23(1)^{*}$ \\
INT & $-1.52(2)$ & $-5.14(1)^{*}$ & $0.53(2)$ & $-1.75(0)^{* * *}$ & $0.72(5)$ & $0.36(3)^{*}$ \\
\hline
\end{tabular}

Note: All unit root tests contain an intercept term. *The critical values at a significance level of $1 \%$ in the ADF test and DF-GLS test are -3.62 and -2.62 , respectively. $* * *$ The critical value at a significance level of $10 \%$ is -1.61 . The critical value at a significance level of $1 \%$ in the KPSS test is -0.74 . 
stationarity. Unlike the ADF test, the KPSS test utilizes the Lagrange Multiplier (LM) statistic to test the null hypothesis. If the LM test statistic is higher than the critical value, the null hypothesis stating that the series is stationary is rejected. It is seen that none of the variables are stationary at $I(0)$, and they become stationary when their first difference is taken $(I(1)$ ) (shown in Table I). ADF, DF-GLS and KPSS test statistics are analyzed in a model with an intercept term. Schwartz Information Criterion (SIC) is used to determine the lag length for the unit root test.

As the first differences of the series are stationary, Johansen cointegration test is used to identify the long-run relationship between real loans, real GDP and real interest rate. Before the Johansen cointegration test, however, it is necessary to determine the lag length of the VAR model. This is because Johansen cointegration test is sensitive to the lag lengths [19]. Criteria such as Likelihood Ratio (LR), Akaike Information Criterion (AIC) and SCI are used to determine the lag length of the VAR model, and it is essential that the VAR model with the selected lag length has no problem of autocorrelation or heteroscedasticity. According to the LR test, the determined lag length is three $(k=3)$.

According to Table II, this model was no thaving any autocorrelation, heteroscedasticity and normality problems at $5 \%$ significant level. In other words, this model (VAR (3)) was supported by the reliability of diagnostic tests.

TABLE II: DIAGNOSTIC TESTS

\begin{tabular}{lcc}
\hline \multicolumn{3}{c}{ TABLE II: DIAGNOSTIC TESTS } \\
\hline Autocorrelation & Heteroscedasticity & Normality \\
\hline $9.67(0.38)$ & $111.79(0.38)$ & $7.44(0.28)$ \\
\hline
\end{tabular}

Note: Lagrange-Multiplier (LM) is used to test the presence of autocorrelation among the series. The value used to test the presence of heteroscedasticity is Chi-square. To test normality, Doornik-Hansen test is utilized.

Two likelihood ratios (LR) are used when determining the number of cointegration vectors in the Johansen cointegration test. One of them is the trace statistic and the other one is the maximum eigenvalue. The testing process starts with the testing of the hypothesis stating that there is no cointegration vector $(r=0)$. If this hypothesis is not rejected, the testing process stops as no proof for the presence of cointegration vectors has been found. If the hypothesis is rejected, the process proceeds with the testing of the hypotheses $r \leq 1, r \leq 2, \ldots$ As shown in Table III, the hypothesis stating that there is no cointegration vector $(r=0)$ is rejected by the trace statistic at a level of significance of $5 \%$, but the hypothesis stating that there is a cointegration vector $(r=1)$ cannot be rejected. This result indicates that there is a long-run equilibrium relationship between the three variables. In other words, its root is smaller than 1, which indicates that the model is stable.

TABLE III: JOHANSEN COINTEGRATION RANK TEST RESULTS

\begin{tabular}{lccc}
\hline Null Hypothesis & Eigenvalue & Trace Statistic & 5\% Critical value \\
\hline$H_{0}: r=0$ & 0.531 & $44.503^{*}$ & 35.193 \\
$H_{0}: r \leq 1$ & 0.252 & 15.743 & 20.262 \\
$H_{0}: r \leq 2$ & 0.117 & 4.731 & 9.165 \\
\hline
\end{tabular}

Note: * It shows that the hypothesis is rejected at a level of significance of $5 \%$.

The long-run equilibrium model containing the variables is as follows:

$$
\begin{array}{r}
L O A N=-44.65+4.17 G D P-0.02 I N T \\
(10.335)
\end{array}
$$

According to Equation (1), the effect of real GDP on real loans is statistically significant and positive, whereas the effect of real interest rates on real loans is statistically significant and negative. After determining a cointegration relationship $(r=1)$, the speed of adjustment parameter $(\alpha)$, which is limited to zero, is identified to determine the longrun weak exogeneity [20]. In the weak exogeneity test of the model, the null hypothesis stating that the variable is weakly exogenous can rejected for the real loans variable at 5\% significance level, whereas it cannot be rejected for real GDP and real interest rate variables at the same level of significance. This indicates that the real loans variable is determined within the system.

TABLE IV: WEAK EXOGENEITY TEST RESULTS

\begin{tabular}{lc}
\hline Variables & Weak Exogeneity \\
& $H_{0}=\alpha_{i=0}$ \\
\hline$L O A N$ & $4.90(0.02)^{*}$ \\
$G D P$ & $2.57(0.10)$ \\
$I N T$ & $2.58(0.10)$ \\
\hline Note: ${ }^{a} L R$ test statisticis based on $x^{2}$ distribution, and the probability values \\
\multicolumn{2}{c}{ are given in brackets. ${ }^{\text {b* }}$ It shows the level of significance of $5 \%}$.
\end{tabular}

We can analyze short-run causal relationship between real loans, reel interest rate and real GDP, because of test results of Johansen cointegration test which revealed long-run relationship between these variables. In other words, it must be determined whether the long-run equilibrium relationship involves a causal relationship from real GDP and real interest rate to real loans. Error correction model is used to determine the direction of causality between cointegrated series [21]. It is important to determine the number of lags in the error correction model. The lag length in this error correction model was $2(k=2)$. Based on the results obtained, the reliability of the applied model was also confirmed with diagnostic tests. In other words, this model wasn't having any autocorrelation, heteroscedasticity and normality problems at $5 \%$ significant level.

TABLE V: ERROR CORRECTION MODEL

\begin{tabular}{lllll}
\hline \multicolumn{1}{c}{ Variable } & Coefficient & $\begin{array}{c}\text { Standard } \\
\text { Error }\end{array}$ & t-statistic & Probability \\
\hline LOAN(-1) & 0.036 & 0.1879 & 0.1918 & 0.8491 \\
GDP $(-1)$ & -0.192 & 0.3925 & -0.4908 & 0.6270 \\
INT $(-1)$ & -0.010 & 0.0056 & -1.7694 & $0.0867 * * *$ \\
ECM coefficient & -0.163 & 0.0667 & -2.4514 & $0.0201 * *$ \\
$R^{2}$ & 0.37 & & & \\
Autocorrelation & $9.09(043)$ & & & \\
Heteroscedasticity & $90.54(0.29)$ & & & \\
Normality & $6.56(0.36)$ & & & \\
\hline Note: Lagrange-Multip & & & \\
\hline
\end{tabular}

Note: Lagrange-Multiplier (LM) is used to test the presence of autocorrelation among the series. The value used to test the presence of heteroscedasticity is Chi-square. To test normality, Doornik-Hansen test is utilized.

According to test result of error correction model (Table $\mathrm{V})$, the coefficients of the lagged variables represented the short-run dynamics of the dependent variable. The error correction term in the model was negative and statistically significant. The negative coefficient of the error correction term indicated that the dependent variable procured the short-run adaptation rate for long-run equilibrium. In other 
words, the lagged error term indicated that $16 \%$ of the deviation between the actual values and long-run values of real loans was eliminated in each quarter and that the real loans variable was corrected based on the changes in the real GDP and real interest rate variables. Nevertheless, the coefficient of the real interest rate variable was negative and significant, whereas the coefficient of the real GDP variable didn't significant. This finding indicated that there wasn't any causal relationship from real GDP to real loans, but there was a causal relationship from real interest rates to real loans in the short-run.

\section{CONCLUSION}

This study investigates the short-run and long-run relationships between real loans, real GDP and real interest rates by using an error correction and Johansen cointegration tests, respectively. The cointegration analysis indicates that there is a stable long-run relationship between the variables. The weak exogeneity test is conducted to find out whether the variables are determined within the system, in other words, whether they are exogenous or not. The result of this test indicates that real GDP and real interest rates are weakly exogenous, which may be interpreted as follows: The weakly exogenous real GDP and real interest rate play a key role in determining the long-run movements of real loans, but are not affected by that variable. The negative and significant coefficient of the error correction term in the error correction model indicates that there is a long-run equilibrium relationship between the variables. The effect of real GDP on real loans disappears in the short-run. Therefore, real GDP has an effect on real loans in the longrun, but does not have a significant effect on it in the shortrun. Real interest rate has got minor effect on real loans in the short-run.

\section{REFERENCES}

[1] C. Onuorah and B. A. Ozurumba, "Bank credits: An aid to economic growth in Nigeria," Information and Knowledge Management, vol. 3 , no. 3, pp. 41-50, 2013.

[2] A. Demirgüç-Kunt and E. Detragiache, "The determinants of banking crises in developing and developed countries," IMF Staff Papers, vol. 45, no. 1, pp. 81-109, March 1998.

[3] A. Calza, C. Gartner, and J. Sousa, "Modeling the demand for loans to the private sector in the Euro area," European Central Bank Working Paper Series, no. 0055, pp. 1-33, Apr. 2001.

[4] K. Gattin-Turkalj, I. Ljubaj, A. Martinis, and M. Mrkalj, "Estimating credit demand in Croatia," Croatian National Bank Paper, pp. 1-36, Apr. 2007.

[5] G. L. Kaminsky and C. M. Reinhart, "The twin crises: the causes of banking and balance of payments problems," The American Economic Review, vol. 89, iss. 3, pp. 473-500, Jun. 1999.

[6] G. Dell' Ariccia, E. Detragiache, and R. G. Rajan, "The real effect of banking crises," Journal of Financial Intermediation, vol. 17, iss. 1, pp. 89-112, Jan. 2008.

[7] H. Mahmood, A. Waheed, and S. Khalid, "Role of macroeconomic indicators in banking crisis," Academic Research International, vol. 5, iss. 2, pp. 205-213, March 2014.

[8] A. I. Fernández, F. González, and N. Suárez, "How bank market concentration, regulation, and institutions shape the real effects of banking crises," Journal of International Money and Finance, vol. 33 , pp.19-40, March 2013.
[9] S. Fukuda, "The impacts of bank loans on economic development: an implication for East Asia from an equilibrium contract theory," Regional and Global Capital Flows: Macroeconomic Causes and Consequences, NBER-EASE, National Bureau of Economic Research, Inc., vol. 10, pp. 117-145, 2001.

[10] BDDK, Structural developments in the banking reports. [Online]. Available: http://www.bddk.org.tr

[11] A. Adamopoulos, "The relationship between credit market development and economic growth," American Journal of Applied Sciences, vol. 7, no.4, pp. 518-526, 2010.

[12] K. Tuna and H. Bektaș, "Examining the role of credit volume on economic growth: The case of Turkey," Journal of Financial Researches and Studies, vol. 5, no. 9, pp. 139-150, 2013.

[13] S. Vurur and E. Özen, "The examination of the relationship between deposits bank credits and economic growth in turkey," Uşak University Journal of Social Sciences, no. 6, vol. 3, pp.117-131, 2013

[14] A. Kaya, Ü. Gülhan, and B. Güngör, "Interaction of finance sector and real sector in TurkishEconomy," Journal of Academic Researches and Studies, vol. 5, iss. 8, pp. 2-15, May 2013.

[15] A. İscan, "Economic impact of the contraction in bank credit and development in crisis," Specialization Competencies Thesis of Central Bank of the Republic of Turkey, 2003.

[16] A. Dickey and W. A. Fuller, "Likelihood ratio statistics for autoregressive time series with a unit root," Econometrica, vol. 49, no.4, pp. 1057-1072, Jul. 1981

[17] G. Elliott, T. J. Rothenberg, and J. H. Stock, "Efficient tests for an autoregressive unit Root", Econometrica, vol. 64, no. 4, pp. 813-836, July 1996.

[18] D. Kwiatkowski, P. C. B. Phillips, P. Schmidt, and Y. Shin, "Testing the null hypothesis of stationarity against the alternative of unit root: how sure are we that economic time series have a unit root?" Journal of Econometrics, vol. 54, iss. 1-3, pp. 159-178, 1992.

[19] G. S. Maddala and V. I. Kim, Unit Roots, Cointegration, and Structural Change, Cambridge: Cambridge University Press, 1998.

[20] S. Johansen and K. Juselius, "Maximum likelihood estimation and inference on co-integration with applications to the demand for money," Oxford Bulletin of Economics and Statistics, vol. 52, iss. 2, pp. 169-210, May 1990.

[21] R. F. Engle and W. J. Granger, "Co-Integration and error correction: representation, estimation and testing," Econometrica, vol. 55, no. 2, pp. 251-276, Mar. 1987.

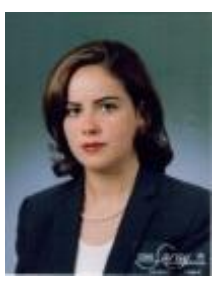

Şehnaz Bakır Yiğitbaş was born in May 1972. She graduated from Uludag University. She completed master and doctorate degree in Kocaeli University. She is working in Canakkale University. Her fields of interest are macro economy and monetary policies. Some of her papers that were published in Journals, such as "An empirical analysis of the relationships between asymmetric information, bank loans and the real sector" in Gaziantep University Journal of Social Sciences, volume11, no. 4, pp. 1248-1274. (With Tar and Kurt); "Parasal Aktarım Mekanizması: Türkiye'de Banka Kredi Kanalı" in Bankacılar Dergisi, no. 85, Haziran 2013, pp. 71-80.

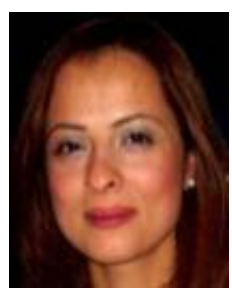

Birgul Cambazoglu was born in September 1977. She graduated from high school in 1995 at Darussafaka College. She completed her B.A. degree in international relations from Uludag University; B.A. degree in international relations from Marmara University, B.S. degree in international economy and PhD degree in economy from Adnan Menderes University. She is working in Adnan Menderes University. Some of her papers have been cited by different authors, such as: "The effect of monetary policy shock on employment and output: The case of Turkey," International Journal of Emerging Sciences, vol. 2, no. 1, pp. 23-29 (with Karaalp); "Monetary transmission mechanism in Turkey and Argentina," International Journal of Economics and Finance Studies, vol. 3, no. 2, pp. 23-33 (with Gunes). Her fields of interest are macro economy, monetary policies and international economy. 